\begin{tabular}{l|l}
\hline & $\begin{array}{r}\text { SISTEMA } \\
\text { ELETRONICO } \\
\text { DE REVISTAS } \\
\text { SER I UFPR }\end{array}$ \\
& muw.ser.ufpr.br \\
& DESENVOLVIMENTO \\
\hline
\end{tabular}

\title{
Assessing Environmental Justice in Large Hydropower Projects: The Case of São Luiz do Tapajós in Brazil
}

\section{Avaliando a Justiça Ambiental em grandes projetos hidrelétricos: o caso de São Luiz do Tapajós, no Brasil}

\author{
Christoph Ernst Emil HESS ${ }^{1 *}$, Wagner Costa RIBEIRO², Silke WIEPRECHT ${ }^{1}$ \\ ${ }^{1}$ Stuttgart University, Stuttgart, Germany. \\ ${ }^{2}$ Universidade de São Paulo (USP), São Paulo, SP, Brazil. \\ *E-mail of contact: christoph.hess@environmentaljustice.de
}

Article received in February 18, 2016, final version accepted in May 1, 2016.

ABSTRACT: Electricity supply in a sustainable manner is one of the greatest challenges for human society today. Hydropower is by far the most important renewable electricity technology, but equally far from uncontroversial. Indeed, it is situated at the crossroads of socio-environmentalism trends, as strongly promoted by some as opposed by other environmentalist arguments, organisations and movements. This paper suggests Environmental Justice as an alternative approach on how to incorporate sustainability into energy planning, particularly in hydropower projects. Whereas several methods have been developed to assess Environmental Justice in an urban context, little attention has been given to electricity projects so far. A qualitative method to assess hydropower projects regarding their performance in Environmental Justice is discussed and illustrated in the case of the large hydropower project São Luiz do Tapajós in the Brazilian Amazon. As will be shown, fundamental change is necessary in Brazil if energy planning in general and hydropower projects in particular are to meet the principles of Environmental Justice.

Keywords: Environmental Justice; hydropower; Amazon; São Luiz do Tapajós; sustainable development.

RESUMO: O fornecimento de energia elétrica numa maneira sustentável se encontra entre os maiores desafios para a sociedade humana hoje em dia. Energia hidrelétrica é de longe a tecnologia de eletricidade renovável mais importante, porém igualmente longe de incontroversa. De fato, se encontra na encruzilhada de correntes socioambientais, tão fortemente promovido por uns quanto rejeitado por outros argumentos, organizações e movimentos ambientalistas. Este artigo sugere a Justiça Ambiental como abordagem alternativa para incorporar a sustentabilidade no planejamento energético, particularmente em projetos hidrelétricos. Enquanto vários métodos foram desenvolvidos para avaliar Justiça Ambiental no contexto urbano, pouca atenção foi dada a projetos elétricos até agora. Um método qualitativo para avaliar projetos hidrelétricos em relação ao seu desempenho em Justiça Ambiental é discutido e ilustrado no caso do projeto hidrelétrico São Luiz do Tapajós, 
na Amazônia brasileira. Como vai ser mostrado, mudanças fundamentais serão necessárias no Brasil para que o planejamento energético em geral e projetos hidrelétricos em específico cumpram os princípios de Justiça Ambiental.

Palavras-chaves: Justiça Ambiental; energia hidrelétrica; Amazônia; São Luiz do Tapajós; desenvolvimento sustentável.

\section{Introduction}

Electricity supply in a sustainable manner is one of the greatest challenges for human society today. Since the endorsement of sustainable development by the United Nations Conference on Environment and Development (UNCED) in 1992, the requirements for electricity supply have changed and the electricity sector had to react towards this new paradigm.

One of the new challenges for the sector is the reduction of greenhouse gas (GHG) emissions by applying renewable energies. The most important renewable source of electricity generation is by far hydropower, accounting for $16.2 \%$ of global electricity production in 2012. Other renewable sources, such as wind, solar and geothermal, amounted to only $5 \%$ (IEA, 2014, p. 24). Hydropower represents more than $85 \%$ of all renewable electricity production and will remain the most important and reliable renewable energy technology for a long time.

However, hydropower is far from uncontroversial, and experiences in the past have shown that changes are necessary to turn hydropower projects environmentally, socially and economically sustainable (WCD, 2000; McCully, 2001; Sousa Junior \& Bermann, 2012; Siciliano et al., 2015).

The Brundtland report famously defined sustainable development: "Sustainable development is development that meets the needs of the present without compromising the ability of future generations to meet their own needs." (WCED, 1987, p. 41) This definition puts a strong emphasis on intergenerational justice, whereas the content of what actually are the "needs of the present" remains vague and subject to interpretation and political struggle. This article suggests the concept of Environmental Justice (EJ) to approach this issue. The common controversy on hydropower projects focusses on the question whether the benefits outweigh the negative impacts or not, or whether the benefits justify the socio-environmental impacts. Morimoto (2013, p. 651), for example, concludes from a multi-criteria analysis of hydropower plants in Sri Lanka that "there is a clear trade-off among economic, environmental and social objectives of hydropower development." In this sense the discussion is often understood as economic development versus environmental conservation. EJ offers an alternative to this deadlock: Given that any hydropower project will generally provide benefits and cause negative impacts, the focus is on how these benefits and impacts will be distributed within society. The centre of attention becomes the allocation of environmental benefits and burdens.

A review of international literature confirms the growing importance of this approach as socioenvironmental conflicts - including conflicts on hydropower - caused by (real or perceived) environmental injustices are increasing worldwide. The allocation of benefits and burdens from hydropower has come into focus in many different countries, such as South Africa and China (Tilt et al., 2008), Sri Lanka (Morimoto, 2013), Laos (Sparkes, 2013), India (Kumar \& Katoch, 2014), Spain (Poma \& Gravante, 2015) and Cambodia (Siciliano et al., 
2015). In Latin America, several studies with a focus on affected communities were conducted in recent years. Poma (2013) and Poma \& Gravante (2015) investigated the role of emotions in protests against hydropower projects in México, Gaviria (2015) identified forms of violence in the Porce III project in Colombia, and epistemological violence and the role of anthropologists in Mexican hydropower are discussed by Gómez Fuentes (2015). Furthermore, conflicts over mining projects have increasingly been recorded and analysed (Bebbington et al., 2008; Romero et al., 2012; Buchanan, 2013), alongside with a focus on indigenous peoples (Acuña, 2015). Hydropower, mining and impacts on indigenous peoples are often interrelated, as hydropower has provided electricity for large scale mining operations (Pinto, 2005; Martínez Alier, 2007 , p. 180) and indigenous peoples are disproportionally affected by both hydropower and mining.

In Brazil this discussion focusses today on hydropower development in the Amazon. Although hydropower is well developed in Brazil and accounted for $65 \%$ of electricity production in 2014 (EPE, 2015, p. 16), the country still holds huge potential. Considering that the installed capacity in September 2015 was 90,302 MW (ANEEL, 2015) and the total potential is estimated at 247,000 MW (Eletrobras, 2014), only $37 \%$ of the potential has already been developed. The bulk of the remaining potential is however located in the north of the country, in the Amazon, which involves two major challenges. First, it is several thousand kilometres away from the country's main consumption centres in the southeast, south and northeast. And second, it involves difficult socio-environmental conditions (Ribeiro, 2010; Sachs, 2010). Most hydropower sites in the Amazon are situated within or close to environmental protection and/or indigenous areas.
Thus, the discussion on the performance of large hydropower projects in the Brazilian Amazon regarding EJ is highly topical. However, no methods to systematically assess EJ exist. Approaches to assess the sustainability of hydropower projects, as for example those discussed by Morimoto (2013) and Skinner \& Haas (2014), do not focus on EJ. On the other hand, whereas several methods have been developed to assess Environmental Justice in an urban context (Moreno Jiménez, 2010), little attention has been given to electricity projects so far (Hernández, 2015, p. 153).

This paper suggests EJ as an alternative approach on how to incorporate sustainability into hydropower projects and aims at contributing to the development of methods for its assessment. It presents the results of a case study on the hydropower project São Luiz do Tapajós (SLT) in the Brazilian Amazon and has six sections beyond this introduction. Section two provides a review of changing paradigms in the Brazilian hydropower sector during the last decades. Section three discusses hydropower and socio-environmentalism trends, followed by a discussion on the application of EJ to hydropower projects in its second sub-section. Section four outlines the applied methodology and discusses its strengths and limits. Section five turns to the case study project SLT and examines whether socio-environmentalism trends can be identified in the stakeholder discourses. Section six discusses the performance of SLT regarding EJ, presenting the results of the case study, followed by conclusions in section seven.

\section{Hydropower in Brazil: Changing paradigms}

In the scope of his Critical Theory of Technology, Feenberg (1992) argues that technical systems 
are "not rigidly constraining but on the contrary can adapt to a variety of social demands" and technology is therefore "a scene of social struggle, a 'parliament of things', on which civilizational alternatives contend." The development of hydropower projects worldwide and in Brazil specifically during the last decades provides a practical example for this theoretical observation.

In Brazil, hydropower was aggressively expanded during the military dictatorship (19641985) when the country's largest dams were built. Little concern was given to socio-environmental impacts during that period. With the end of the dictatorship and the restoration of a parliamentary democracy this practice was no longer politically feasible. Souza \& Jacobi (2013, p. 322, translated from Portuguese) wrote:

The democratisation process of the Brazilian society also affected the electric sector, which had to review a series of hydroelectric projects that had been planned still under the dictatorship, like the hydropower plants Belo Monte, Jirau and Santo Antônio whose original technical projects were modified in order to respond to the political and social demands of the post-dictatorship Brazil.

A major change was the introduction of an obligatory Environmental Impact Assessment (EIA), regulated by law still under the dictatorship in 1981 and included in the new Constitution of 1988 (Chapter VI, Art. 225). Bermann (1991, p. 234) states that environmental studies, non-existent or superficial before, became now fundamental to politically enable hydropower projects.

On this background, large hydropower projects in the Amazon suffered considerable modifications. The conditions for hydropower development in the Amazon are in general determined by high discharges, low to moderate slopes and plain topographies, resulting in large reservoir areas and hence evenly large socio-environmental impacts, despite of the relatively low population density. The most notable negative impacts include: flooding of native forest and its impacts on biodiversity; decline of fish populations, especially migrating fish which are of high importance for (subsistence) fishery; negative impacts on water quality (eutrophication) and related health concerns for drinking water supply; mobilisation and methylation of mercury; negative impacts on traditional populations, notably indigenous peoples and traditional riverine settlers (ribeirinhos); greenhouse gas emissions; and socio-economic impacts on municipalities and communities due to large labour migration and resulting economic activities (Sevá Filho, 2008; El Saifi \& Dagnino, 2011; Zhouri, 2011; Sousa Junior \& Bermann, 2012; Von Sperling, 2012; Rosa, 2013; Fearnside, 2015a).

In order to reduce these impacts the projected plants in the Amazon were redesigned as run-ofriver (RoR) plants (Rosa, 2013). In this configuration a plant produces electricity in conformity with the river hydrology, without storing water, thereby considerably reducing the reservoir size. The ratio between installed power and reservoir area for Belo Monte, for example, is $20 \mathrm{MW} / \mathrm{km}^{2}$, compared to a national average of approximately $2 \mathrm{MW} / \mathrm{km}^{2}$ (Gobbi, 2013). The foreseen ratio for São Luiz do Tapajós is $11 \mathrm{MW} / \mathrm{km}^{2}$. In comparison, the ratio for the existing Amazonian plants Balbina and Tucuruí are 0.1 and $2.9 \mathrm{MW} / \mathrm{km}^{2}$, respectively (Rosa, 2013). This development is not confined to Brazil. According to Kumar \& Katoch (2013, p. 101-102, 108), a shift from storage to RoR hydropower plants driven by concerns over socio-environmental impacts can also be observed in India and other countries. 
For Souza and Jacobi (2013, p. 341) the redesign as RoR plants corresponds to an ecological modernization process and the authors argue that the Brazilian state has sought to reconcile two demands at stake: the expansion of the hydroelectric park and the implementation of projects with lower impacts.

The reduction of the reservoir area has the important advantages of less direct impacts on biodiversity (flooded area) and less people to be resettled. Moreover, the lower water retention time in the reservoir potentially reduces negative effects on water quality, and the natural discharge regime of the river, which provides important ecological functions, is maintained.

However, the RoR design has also some important disadvantages. It reduces or eliminates the possibility to react to fluctuations in electricity demand, which is a strong operational benefit of storage hydropower plants. Therefore RoR plants are typically used as base load plants and their ability to cover mean and especially peak load is limited (Giesecke et al., 2014, p. 63-64). Additionally, RoR plants have limited or no utility for flood control (Instituto Acende Brasil, 2013, p. 5).

Because of this new configuration of hydropower plants Ventura Filho, Secretary of Energy Planning and Development at the Ministry of Mines and Energy (MME), refers to a new phase of hydropower development in Brazil. According to the author, the first phase was characterized by large storage plants, mainly located in the Paraná and São Francisco River basins. The second and current phase will be characterized by large RoR plants in the Amazonian river basins Xingú, Madeira and Tapajós (Ventura Filho, 2015).

\section{Hydropower, socio-environmentalism and Environmental Justice}

\subsection{Hydropower at the crossroads of socio-environmentalism trends}

In order to understand the disputes on hydropower projects it is useful to examine existing differences in (socio-) environmentalism. Martínez Alier (2007) distinguishes three trends: the Cult of the Wildlife, the Creed of Eco-efficiency and Environmental Justice / Ecology of the Poor.

Whereas certain technologies and related projects may be embraced or opposed by all of these trends, hydropower is much more controversial, especially large plants. Large hydropower fits well into the eco-efficiency approach, particularly under the discussion of decreasing GHG emissions. Additionally, the implementation of large hydropower plants allows the embracement of an eco-efficiency discourse without major changes in the developed technological, economic and political structures and it is lucrative for involved private companies. Large projects also deliver large amounts of electricity designated as renewable and clean. Dams are, for example, a major destination of subsidies by the Kyoto Protocol's Clean Development Mechanism, including in Brazil (Fearnside, 2015a).

Large hydropower projects are, on the other hand, criticised due to their large socio-environmental impacts, the uncertainties about real GHG emissions (Mendonça et al., 2012; Fearnside, 2015a) and negative experiences in the past (WCD, 2000; McCully, 2001; Sousa Junior \& Bermann, 2012). Additionally, due to their location in rural areas they are likely to affect poor rural communities and traditional populations disproportionately, whereas most benefits are generated in urban areas far away 
from the dam (Siciliano et al., 2015). Therefore the implementation of large HPPs has led to many socio-environmental conflicts throughout the world. Martínez Alier (2007, p. 178, translated from Portuguese) sees a global North-South difference in the character of struggles against hydropower projects:

In the North, the opposition to dams often arises from groups of people who are worried about the disappearance of natural beauties or because of the loss of pleasures like rafting down the rapids of a river. In the South, the antagonism originates, like with the movement of the dam affected [emphasis in the original] of Brazil, from a population disposing of modest means in danger to lose their source of subsistence.

This perception coincides with the interpretation of the socio-environmental trends Cult of the Wildlife and Ecology of the Poor. But Martínez Alier also adds that although in the South the "material survival" is often the fundamental value and motivation of protests against dams, this is perfectly compatible with "the sacred, the esthetical and with the respect devoted to all forms of living beings."

With this the setting of hydropower at the crossroads of socio-environmentalism trends can be characterized: it is endorsed and promoted by the Creed of Eco-efficiency and often opposed by an alliance between Environmental Justice / Ecology of the Poor and The Cult of the Wildlife.

\subsection{Environmental Justice applied to hydropower}

Primarily, EJ refers to the distribution of environmental benefits and burdens: no group of people, including ethnical, racial and social groups, should bear a disproportionate burden of negative environmental consequences from economic activity or due to the execution as well as the absence of public policies (Acselrad et al., 2008, p. 16). In this framework of distribution large hydropower plants for electricity production (excluding other purposes) represent an imbalance: the impacts are highly concentrated on the region whereas the benefits (electricity) are largely exported. The larger the plant and the higher the fraction of exported electricity, the stronger this imbalance becomes. Moreover, the impacts within the affected region are concentrated further with the highest burden on the displaced and directly affected people, which are often poor, rural, traditional and/or indigenous communities. This pattern of distributional imbalance was found in many hydropower projects throughout the world (Siciliano et al., 2015, p. 274) and can therefore be considered a general (large) hydropower problem.

However, Schlosberg (2007) calls attention to the fact that distribution cannot fully explain the whole dimension of EJ. He suggests the consideration of different dimensions of justice, including distribution, recognition and procedure ${ }^{1}$, and argues: "Within the environmental justice movement, one simply cannot talk of one aspect of justice without it leading to another." (Schlosberg, 2007, p. 73)

Recognition refers to the right of social, ethnical, racial, gender and other groups (and also individuals) to be recognized by the state, authorities, companies or the society in general. Misrecognition can be a general practice of cultural domination, a non-recognition or disrespect ("being routinely maligned or disparaged in stereotypic public and

\footnotetext{
1 Additionally, Schlosberg also suggests the community capabilities approach, which incorporates elements of all the three mentioned dimensions. This approach will not be discussed in this article.
} 
cultural representations") (Schlosberg, 2007, p. 18). This aspect is of importance in hydropower projects regarding the recognition of all affected people. In many projects throughout the world the amount of affected people has been consequently under-estimated and frequently whole affected groups have been omitted, to which Sousa Junior \& Bermann (2012) refer to as the invisibility phenomenon. Recognition is further especially important for traditional and indigenous populations. Schlosberg (2007, p. 87) identifies two key demands of indigenous peoples related to recognition:

The first is a simple call for the recognition that indigenous populations exist in places where the majority culture does not necessarily see them; the second is that indigenous traditions, cultures, and ways of life need to be recognized and respected as alive, valid, and on par with other cultures.

Another important aspect regarding hydropower is the recognition and appreciation of different kinds of knowledge. Acselrad et al. (2008, p. 22) argue that the recognition of workers', ethnical groups' and local communities' knowledge as equally relevant to other forms of knowledge is part of the EJ principles. The claim to local forms of knowledge, dismissed by authorities, was found in socio-environmental conflicts, as for example by Buchanan (2013).

Procedural justice refers to how projects are implemented. One of its central aspects is participation in decision-making, which is closely linked to distribution and recognition, as injustices in the latter two hinder the ability of individuals and communities to participate (Schlosberg, 2007, p. 26). Moreover, a just outcome in distribution is commonly associated to participation, as Moreno Jiménez (2010, translated from Spanish) puts it:
"One can assume, a priori, that the adequate (to define) and effective participation of all stakeholders of a situation or project intervention leads to a just decision, although it might not always be correct."

It can therefore be concluded that justice in distribution, recognition and procedure are interrelated and-dependent, all three of them corresponding to important dimensions of EJ, as illustrated in Figure 1.

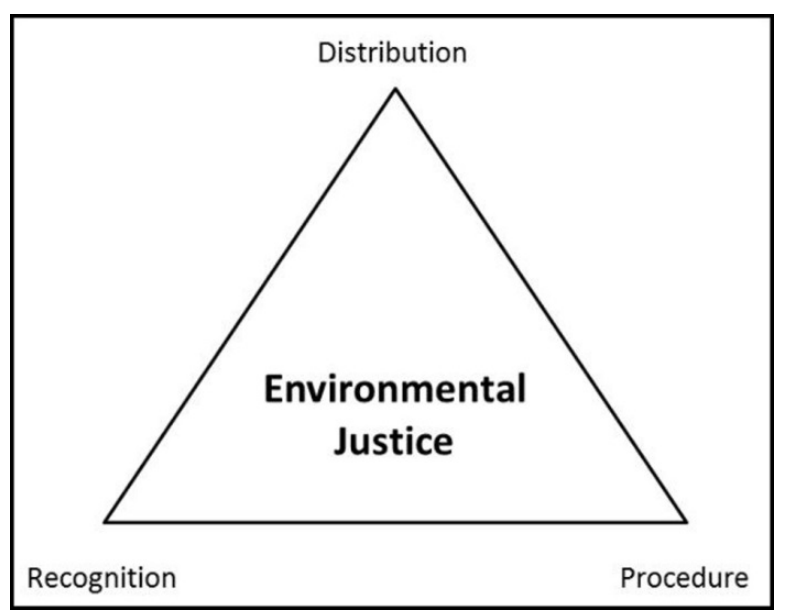

FIGURE 1 - Interdependent dimensions of Environmental Justice (created by Hess, 2015).

Aspects of procedural injustice were found in many hydropower related conflicts, as for example recorded by Poma (2013) and Poma \& Gravante (2015). To meet the principle of procedural justice in hydropower, a participation of all stakeholders at an early planning stage is necessary. However, procedural justice goes beyond participation, and other important aspects as the procedure and scope of Environmental Impact Assessments and the process of resettlement programmes can be addressed under this concept, as will be shown in section six of this article. 


\section{Methodology}

In the present case-study semi-structured qualitative interviews were conducted with representatives of different stakeholder groups ${ }^{2}$. The stakeholder groups were pre-defined based on a review of secondary sources - including journalistic and academic articles, the Environmental Impact Assessment and press releases - and this definition was refined after the interview analysis. For the analysis, a theoretical interpretation according to the EJ framework as developed in section three was applied. Based on the findings, relevant aspects for each of the three defined dimensions of EJ were identified, and the performance of São Luiz do Tapajós project in these aspects was then qualitatively assessed based on available information, leading to a conclusion for each dimension.

This methodology has proven very effective in building a structural outline of the conflict situation and the standing of its main stakeholder groups. It shows, however, some important limitations regarding its capability of reflecting the dynamic nature of complex stakeholder processes. As Nascimento (2001, p. 95-97) points out, social actors in conflicts are never static, but move constantly and change their positions and strategies. Furthermore, their movements are not always clearly perceptible and their discourses not always coherent. Poma \& Gravante (2015) highlight the role of emotions in conflicts over dams and argue that in order to understand its dynamics a comprehensive study of the "infrapolitics", "informal leaderships" and "non-elites", especially regarding the affected communities and individuals, is necessary.

The applied methodology in this case study remains therefore on a structural basis and reflects the situation at the time when the study was conducted (June - December 2015). Having these limitations in mind, it serves well for the designed purpose, as will be shown in the following sections.

\section{São Luiz do Tapajós and socio-environmentalism: Do the stakeholders follow a trend?}

This section examines whether the stakeholders' discourses in the case of São Luiz do Tapajós (SLT) confirm the distinction of socio-environmentalism trends as developed by Martínez Alier (see section 3.1).

The interviews revealed that the stakeholder groups who support the project (proponents) use an eco-efficiency discourse. This is most evident in a statement issued by the consortium "Grupo de Estudos Tapajós" (GET, composed of the companies responsible for the Environmental Impact Assessment studies), which includes the following paragraph on benefits of the project:

The hydropower plants in the Tapajós River will guarantee the safe supply of clean and renewable energy with a positive impact on the environment [emphasis added]. They will also bring benefits to the local population, with the generation of employment and income and they will permit the economic and social development of the region and the country.

Hence, for the consortium there is no contradiction between the construction of large dams and the environment. They even see "a positive impact on the environment". The government, represented by the Ministry of Mines and Energy (MME), on the other hand sees also negative impacts, which can

${ }^{2}$ All interview citations in this article were translated from Portuguese. 
however be mitigated or compensated: "In every hydropower project there are positive and negative environmental impacts, which are presented in the Environmental Impact Assessment. The negative impacts are subject to mitigation and compensation measures." Compensation measures are understood as "necessary actions to create positive impacts which compensate the impacts that cannot be mitigated."

The central assumption of the eco-efficiency trend - technological innovation can and will eliminate the contradiction between economic development and environment - is evident in this argumentation. The compensation approach, as argued by the MME, indicates another important aspect of eco-efficiency: to "compensate the impacts which cannot be mitigated" is a strategy to internalize the externalities (Martínez Alier, 2007, p. 28).

The approach can therefore be summarized as applying mitigation measures which "eliminate or minimize" the negative impacts and internalize the costs of the remaining impacts by means of compensation measures.

For these stakeholders the problems can be resolved to a large extend by that strategy. Remaining conflicts, in the view of the MME, are due to lack of information: "There are people who believe that the financial resources coming to the region will bring many opportunities of income and employment, while others fear for their future, often because of the lack of qualified information." And this problem will finally be resolved by a "Communication Plan".

In contrast, the opponents of the project embrace a discourse which can be allocated in the field of Environmental Justice/Ecology of the Poor (EJ/ $E P)$. The first interview question was about environmental impacts of the project, followed by impacts on the region in the second question. The interview posed therefore a separation between environmental and socio-economic impacts, and the proponents followed this separation in their answers. However, almost all interviewed opponents referred to negative impacts on the region, people and communities already in the first question. For the opponents the impacts on the environment are inseparably linked to the socio-economic impacts, as is for example evident in the answer from the representative of the social movement "Pastoral Land Commission" (CPT) to the first question:

The project is negative, from the point of view of environment, of preservation, from the point of view of sustainability, and the staying of the people in the countryside. The riverine settler, the fisher, the indigenous people, the culture of these people, how they live, from fishery, from craft work, for these people it is a negative impact, along the whole Tapajós River.

Other important aspects of the EJ/EP trend are for example a critical relation to technology and technological solutions and the incommensurability of values (Martínez Alier, 2007) which were also present in the opponents' interview answers.

The interviews revealed therefore that Martínez Alier's definition of the two environmentalism trends Eco-efficiency and Environmental Justice/ Ecology of the Poor can be recognized in the discourses of stakeholders in the case of SLT. It further confirms the hypothesis of hydropower at the crossroads of socio-environmentalism trends, as argued in section 3.1. In the SLT project these two trends, both embracing an environmental discourse, stand in direct opposition to each other.

The Cult of the Wildlife trend was not identified in the stakeholder interviews. However, important elements of it are included in the discourse of the Munduruku, which confirms its connection to indigenous people (Martínez Alier, 2007, p. 23). 


\section{Environmental Justice applied to São Luiz do Tapajós}

SLT is projected to be built in the Tapajós, a major tributary of the Amazon River, and is the largest plant out of the "Complexo Tapajós", a complex of five large plants. SLT is planned as a run-of-river plant with an installed capacity of 8,040 MW. Its rockfill dam will be $7,608 \mathrm{~m}$ long and at its maximum $33 \mathrm{~m}$ high. Its reservoir will have a surface area of $729 \mathrm{~km}^{2}$ and a maximum extension of $123 \mathrm{~km}$ along the Tapajós River (CNEC Worley Parsons, 2014, Volume 1, p. 91, 102, 149).

These data give an idea about the dimension of the project and why it leads to widespread discussions in the area, which are further heated by the presence of indigenous peoples (out of which the Munduruku is the most expressive one) and traditional riverine settlers (ribeirinhos) in the river basin. The Environmental Impact Assessment (EIA) was handed in to the responsible authority IBAMA in August 2014 and has been under revision due to demands from the authorities FUNAI (indigenous peoples) and IBAMA (environment). In April 2016 IBAMA cancelled the licensing process due to the plant's impacts on the Munduruku.

The following sub-sections present the results of the EJ assessment.

\subsection{Distributional justice}

The assessment of SLT regarding distributional justice is summarized in Table 1.

The central aspect regarding distributional justice is the allocation of the electricity generated by the future plant, which is its only purpose. In this aspect SLT represents an extreme case, as the electricity will be nearly entirely exported. According to the EIA (CNEC Worley Parsons, 2014, Volume 1, p. 14), the "primordial objective" of the plant is to expand the supply of electricity for the Southeast, South and Centre-West of Brazil.

TABLE 1 - Performance of SLT regarding distributional justice.

\begin{tabular}{|c|c|c|}
\hline Dimension & Relevant aspects & Conclusion \\
\hline Distribution & $\begin{array}{l}\text { - Imbalance of electricity consumption: local } \\
\text { region will suffer the impacts but only use very } \\
\text { little or even nothing of the produced electricity } \\
\text { - From the point of view of local or regional } \\
\text { consumption the project cannot be justified } \\
\text { - Compensation measures may benefit local } \\
\text { region } \\
\text { - Local businessmen want a political strategy for } \\
\text { local industrial development (lower energy prices) } \\
\text { - Fundamental conflict on the mode of } \\
\text { appropriation of nature with indigenous population } \\
\text { - Incommensurability of values in the case of } \\
\text { directly affected population, riverine settlers and } \\
\text { indigenous peoples }\end{array}$ & $\begin{array}{l}\text { Explanation: } \\
\text { The available information - taking into account the } \\
\text { local conditions, the plant layout and its expected } \\
\text { benefits and impacts - indicates strongly that the } \\
\text { SLT project will have a poor performance in terms } \\
\text { of distributional justice, both in regard to the local } \\
\text { urban and to the traditional populations (indigenous } \\
\text { and riverine communities). }\end{array}$ \\
\hline
\end{tabular}


Different to the EIA, the Diálogo Tapajós, a communication group hired by the consortium, argues in one of its brochures (Diálogo Tapajós, n.d.) that the local region will also receive the electricity. However, data on electricity production and consumption reveal that there is no justification for a plant of the size of SLT, let alone a complex of five or more plants, from the point of view of local or regional demand. The whole northern region of Brazil, consisting of seven states including Pará (where the SLT site is located), consumed 38,233 GWh in 2014 according to the MME (2014, p. 39), equivalent to $7.9 \%$ of the Brazilian electricity consumption. On the other hand, in September 2015 the installed capacity in the North was equivalent to $14.8 \%$ of the Brazilian capacity (ANEEL, 2015). The MME foresees that this imbalance rises to $8.3 \%$ in consumption and $23 \%$ in installed capacity by 2023 (MME, 2014, p. 77).

The MME argues that the region will still benefit from the plant by royalty payments, investments and economic acceleration. From the point of view of a local businessmen's representative, for whom the plant means "development", some more has to be done to include the region adequately in the benefits of the project:

We are preparing a suggestion to the government and Eletrobras that if we are energy producers we should have a lowering of energy prices in our region, a differentiated price, so that the industries can come to our region. [...] And we have a project to be presented that if we have a differentiated energy price here, and the industries come to operate here, their products could be exported as to the centre and south of Brazil, as to Europe, USA and Asia.

This is a proposal on how distributional justice could be approached within the existing project. Its chance of implementation remains to be seen, but it carries rather complicated political implications: if conceded, it would probably lead to (justified) demands of many other municipalities which already received large projects in the past.

Furthermore, the suggestion still doesn't justify a project with the size of SLT. Rather, an energy planning starting from the necessities of the region and municipalities, including an economic planning how a local beneficiary production chain could be supported and implemented, would be the starting point of such approach. A first project with a more balanced relation between regional electricity supply and export - e.g. 50:50 or 30:70 - could be implemented and later evaluated in terms of local development and negative socio-environmental impacts. The current energy planning of the Brazilian government goes the other way round: the federal government projects the increase of electricity demand for the whole country and turns to the Amazon for electricity extraction. Hence, for many opponents the hydropower plans of the government follow a historic logic of exploitation of the Amazon.

Another important factor is that the most affected groups by SLT are among the socially most vulnerable ones, including the communities in the area of the future reservoir, the riverine settlers and the indigenous people. If a positive (economic) development of the region is to occur, specific measures will be necessary to include these people into this development. The resettlement of the directly affected population as well as the impacts on the indigenous people and riverine settlers involves the incommensurability of values (Martínez Alier, 2007; Moreno Jiménez, 2010), which means that these impacts cannot be entirely measured in monetary terms.

As a conclusion, the available information taking into account the local conditions, the plant 
layout and its expected benefits and impacts - indicates strongly that the SLT project will have a poor performance in terms of distributional justice, both in regard to the local urban and to the traditional populations (indigenous and riverine communities).

\subsection{Justice in recognition}

The assessment of SLT regarding justice in recognition is summarized in Table 2 .

Regarding the recognition of affected people, the Brazilian licensing process shows a serious flaw in not taking into account the whole river basin. Although the national law 9.433/1997, which implemented the "National Policy of Water Resources" in Brazil, defines the river basin as the territorial unit of water management, this is not applied in the licensing process of HPPs in general and SLT specifically. The EIA defines the two municipalities Itaituba and Trairão as "area of indirect influence" (AII) regarding socio-environmental impacts (CNEC Worley Parsons, 2014, Volume 2, p. 248). On the other hand, the same EIA recognizes impacts of the dam which transcend these limits, especially regarding the impacts on migratory fish fauna, which it defines as highly important "because the affected species are widely distributed and are strategic for the aquatic communities and fishing" (CNEC Worley Parsons 2014, Volume 23.1, p. 206).

This is contradictory and implies that the affected riverine settlers downstream (and potentially also upstream) of the dam will not be recognized. This is furthermore especially problematic because the problem is well-known in Brazil and caused several conflicts in the past (Vainer, 2007).

A second aspect is the recognition of land rights and religious values of the Munduruku. One of the most critical issues in the licensing process is the demarcation of the Munduruku land "Sawré Muybu". This land would be partly flooded by the future reservoir and has been in a demarcation process since 2001. In the understanding of many stakeholders, the recognition of this land would turn the construction of the plant in its current layout unconstitutional, because article 231 of the Brazilian Constitution forbids "the removal of indigenous groups from their land". The reservoir of SLT would remove three Munduruku villages (Fearnside, 2015b, p. 375). Hence, most opponents evaluate that "Sawré Muybu" is not being demarcated because of the plant. A representative of the National Prosecution Service (MPF, acronyms in Portuguese) argued:

TABLE 2 - Performance of SLT regarding recognition

\begin{tabular}{lll}
\hline Dimension & \multicolumn{1}{c}{ Relevant aspects } & Conclusion \\
\hline & $\begin{array}{l}\text { - Recognition of all affected people in the river } \\
\text { basin. Especially important in regard to riverine } \\
\text { settlers. }\end{array}$ & SLT fails in terms of justice in recognition. \\
& - Recognition of special socio- economic & Explanation: \\
Recognition & conditions of riverine settler communities. & $\begin{array}{l}\text { SLT failed so far in recognition of indirectly affected } \\
\text { people in the Tapajós River basin beyond the defined } \\
\end{array}$ \\
& $\begin{array}{l}\text { - Recognition of land and religious rights of the } \\
\text { "Munduruku. Conflict on perception of nature } \\
\text { and inundated land. Munduruku claim a sacred influence", in the recognition } \\
\text { space. }\end{array}$ & $\begin{array}{l}\text { of special socio-economic conditions of riverine } \\
\text { communities and is likely to also fail in recognition } \\
\text { of the Munduruku's cultural and religious rights. }\end{array}$ \\
\hline
\end{tabular}


This is not my personal opinion. This is proven by documental evidence, during hours of meetings which I had with the FUNAI (responsible authority for the demarcation of indigenous land, editor's note), and declarations of the FUNAI's ex-president Maria Augusta Assirati, when she was still in office as well as after she left. Nine days after this declaration, when she was still in office, she resigned, in a quite absurd way. So this is not an opinion of the Federal Prosecution Service, this is evident.

The question is further complicated by the fact that the Munduruku claim a sacred place in exactly the area which is going to be flooded, as two Munduruku representative declared in their interviews. In contrast, a representative of Diálogo Tapajós declared in a personal conversation that in reality it was not a sacred place for them, suggesting the utilization of this argument in an unjustified manner. Thus, there is a conflict on the recognition of the cultural and religious values of the Munduruku, which includes the recognition of knowledge. In April 2016 the FUNAI (responsible authority for indigenous peoples) published a report officially recognizing "Sawré Muybu", and the environ- mental authority IBAMA cancelled thereupon the licensing process of SLT.

A third aspect concerns the recognition of riverine settlers as traditional people, leading to the question whether they should be included in the consultation process in the scope of the ILO Convention 169. This question cannot be answered in the scope of this work. However, the vulnerability of these communities is evident and recognized by the EIA itself, which indicates that a special attendance to their differentiated social and economic conditions would be adequate.

Concluding, the project SLT failed so far in recognition of indirectly affected people in the Tapajós River basin beyond the defined "area of indirect influence", in the recognition of special socio-economic conditions of riverine communities and is likely to also fail in recognition of the Munduruku's cultural and religious rights.

\subsection{Procedural justice}

The assessment of SLT regarding procedural justice is summarized in Table 3 .

TABLE 3 - Performance of SLT regarding procedural justice.

\begin{tabular}{|c|c|c|}
\hline Dimension & Relevant aspects & Conclusion \\
\hline \multirow[b]{3}{*}{ Procedure } & - Consultation of the Munduruku & SLT fails in terms of procedural justice. \\
\hline & $\begin{array}{l}\text { - Reallocation of the consultation and } \\
\text { Environmental Impact Assessment to an earlier } \\
\text { stage in energy planning (taking it into account } \\
\text { for decision making) }\end{array}$ & $\begin{array}{l}\text { Explanation: } \\
\text { The government has failed so far in establishing } \\
\text { a proper dialogue for consultation with the }\end{array}$ \\
\hline & $\begin{array}{l}\text { - Integrated Environmental Impacts Assessment: } \\
\text { Integration of adequate spatial dimension (river } \\
\text { basin) and other important socio-economic } \\
\text { transformations in the region (ports, roads, other } \\
\text { plants) } \\
\text { - Fair resettlement process }\end{array}$ & $\begin{array}{l}\text { Munduruku. Furthermore, more fundamental changes } \\
\text { would have to be implemented to meet the principles } \\
\text { of procedural justice: the consultation of affected } \\
\text { populations and indigenous peoples as well as the } \\
\text { EIA should be reallocated in the decision process and } \\
\text { start at an earlier planning stage, and the latter should } \\
\text { be amplified to an integrated approach. }\end{array}$ \\
\hline
\end{tabular}


A central issue of procedural justice in the case of hydropower projects affecting indigenous peoples is their "free, prior and informed" consultation as foreseen by the ILO Convention 169. The evaluation of this process differs strongly between the government and Munduruku representatives so far. For the MME the government "has been making efforts for years" and had "countless meetings with indigenous peoples of the Tapajós basin". A Munduruku representative, in contrast, told in the interview that a consultation was not happening at all and the government never came to talk to them. In June 2015 the court of Itaituba determined the necessity of a proper consultation process before issuing the license to build SLT, and this has been one of government's central challenges to proceed with the licensing.

A proper consultation process is important, however Acuña $(2015$, p. 91) suggests that "[...] important socio-environmental conflicts that involve indigenous peoples are not simply a problem of ill-designed policies; they rather emerge because of the permanence of a colonial pattern of domination that denies indigenous ontologies." According to this view, the conflict cause is much more likely located in the realm of distribution and recognition, but the conflict is articulated within the procedural realm as indigenous people have recognized rights here which they can reclaim.

There is also a fundamental problem in the way the consultation is conducted in Brazil. In order to turn the process effectively "free, prior and informed", the consultation should happen before the final decision to build a plant. In the current energy planning, however, the government decides which plants to build where and when, and then a consultation can be conducted. The plant appears as an accomplished fact, which cannot be considered a free and prior consultation. The example shows that the consultation is not yet part of the energy planning in Brazil.

Another important issue of procedural justice is the scope of the environmental impact studies and the licensing process. In order to achieve a fair procedure and also a realistic overview of benefits and negative impacts, the decision processes regarding hydropower projects have to be made in the scope of an integrated water resources management. This integration has two elements. First the spatial dimension. An integrated procedure would include all hydropower projects in the river basin and evaluate their cumulative effects, as recommended by the World Commission of Dams (WCD, 2000 , p. 269). This is in principle also recognized in Brazil. In the case of Tapajós, an Integrated Environmental Evaluation of the Tapajós Basin was developed and presented by the consortium GET in 2014. However, this integrated evaluation has no relevance for the licensing process, which proceeds on a project scale.

The second element of integration concerns other relevant and major socio-economic projects and transformations in the region. As Sclove (1999, p. 19) argues, "clusters of focally unrelated technologies often interact non-focally to produce structural results that no one technology would produce alone." This applies to the Tapajós in the current situation, given that the whole basin is in a transformation process, including the implementation of Complexo Tapajós, the construction of harbours for the exportation of agricultural commodities and associated road infrastructure. A comprehensive assessment of socio-environmental impacts has to take the cumulative effects of these transformations into account.

Furthermore, the criticism on the consultation process that it is only implemented after the decision making also applies to the EIA. In the present 
energy planning, the decision regarding hydropower (and other) plants is made by the government prior to the EIA, i.e. before the impacts of a project are actually evaluated. This is an important limitation of the assessment as an instrument of environmental policies and is also not in conformity with procedural justice. Likewise, Siciliano et al. (2015, p. 283) derive from their case study in Cambodia the necessity of an "open decision making to cope with the many social and environmental challenges large dams bring about."

A fair procedure is furthermore an important aspect concerning the resettlement of the directly affected population. The EIA(CNEC Worley Parsons, 2014a, Volume 24.2, p. 12-14 \& p. 28-29) foresees a comprehensive process, including four different compensation options, the provision of three locational options in the case of collective resettlement, and the installation of public discussion forums. It can be concluded that the EIA includes procedural justice in this case, but the implementation in practice remains to be seen.

In conclusion, the government has failed so far in establishing a proper dialogue for consultation with the Munduruku in the case of SLT. Furthermore, more fundamental changes would have to be implemented to meet the principles of procedural justice: the consultation of affected populations and indigenous peoples as well as the EIA should be reallocated in the decision process and start at an earlier planning stage, and the latter should be amplified to an integrated approach.

\section{Conclusions}

As shown in this article the projects of large hydropower plants in the Brazilian Amazon were reconfigured during the last 15 years in an attempt to respond to socio-environmental demands. For some authors (Souza \& Jacobi, 2013) this process was, albeit including its shortcomings, rather successful.

However, the present case study shows that SLT, as an example for another large hydropower project, did not considerably improve its performance if assessed under an EJ approach. The applied changes have decreased the negative impacts deriving from large reservoirs but did not change the fundamental setting of the project within the Brazilian energy planning. For the local population the price to pay remains high and the benefits low and/or doubtful. In the present configuration, the Tapajós will likely become an "energy sacrifice zone" (Hernández, 2015).

The fundamental question at stake with SLT and other similar projects lies at the setting of these projects and the Brazilian electricity planning: Can a large hydropower project (or, more precisely, a set of large hydropower projects) built in the Amazon, aiming at providing electricity to the main consumption centres of the country thousands of kilometres away, be environmentally, socially and economically sustainable? The information raised in the scope of this case study indicates a no as the answer to this question. Interpreting sustainability in an EJ approach, SLT can be considered unsustainable.

The economic development of Brazil has been extremely unbalanced, with large cities concentrating the population, industries, services etc., having to reach further and further to satisfy their demands in natural resources necessary to sustain their social and economic functioning, such as food, water, raw materials and electricity. The current planning of large hydropower plants in the Amazon consolidates and even intensifies this development. It is, in a certain understanding, the ultimate manifestation of this development in the Brazilian context. There 
is little evidence of a positive development, which can be considered as sustainable, induced by such projects in the Amazon and, on the other hand, strong evidence of their negative impacts.

This paper suggests EJ as an alternative approach on how to incorporate sustainability into energy planning, particularly hydropower projects. Evidently this approach is not intended to replace other important instruments, but could for example be integrated into the environmental impact assessment studies. It was shown that EJ is an effective concept for the assessment of socio-environmental impacts, addressing for example the necessity of an integrated approach, the recognition of all affected people on a proper spatial scale and the reallocation of important instruments, including the EIA, in the decision making process. Additionally, EJ requires the consideration of a possible incommensurability of values, which could be an important instrument to improve resettlement programs and evaluate the effects on indigenous and other traditional populations. Finally, EJ requires the fair distribution of benefits and burdens from electricity projects. A general growth in electricity consumption is often taken for granted without a proper discussion on the use of this electricity (Ribeiro, 2014).

A review of international literature on hydropower conflicts confirms the relevance of the defined aspects and the developed method in this case study. Although the assessment of EJ in hydropower projects is evidently site and context specific, many aspects - such as the imbalance in exported benefits and local impacts, improper and incomplete contemplation of local interests and compensation measures, non-recognition of incommensurability of values and specific cultural needs and the poor performance regarding stakeholder participation processes and decision making - have been reported in many hydropower projects throughout the world.

The case study revealed that EJ has to be implemented in energy planning at an early stage. It cannot be "added" or integrated afterwards to a project, but has to be part of the decision making in energy planning, because environmental injustices are embodied in specific electricity projects, as in the case of SLT. Mitigation and compensation cannot address these injustices in a satisfying manner. It was shown that fundamental change is necessary in Brazil if energy planning in general and hydropower projects in particular are to meet the principles of Environmental Justice.

\section{Disclosure statement}

The researcher Christoph Ernst Emil Hess received a grant by the Hans Böckler Foundation (HBS) during his Master studies. The HBS did not at any moment in any way influence the present research, including the collection, analysis and interpretation of data, the writing of the report or the decision to submit this article for publication.

\section{Acknowledgements}

First of all, we would like to thank every interview partner for the collaboration with this study. Furthermore, we would like to thank the Hans Böckler Foundation for the grant during the Master studies, and the anonymous reviewer of this article for the valuable comments. 


\section{References}

Acselrad, H.; Mello, C. C. A.; Bezerra, G. N. O que é Justiça Ambiental. Rio de Janeiro: Garamond, 2008.

Acuña, R. M. The politics of extractive governance: Indigenous peoples and socio-environmental conflicts. The Extractive Industries and Society, 2, 85-92, 2015. doi: 10.1016/j.exis.2014.11.007

ANEEL - Agência Nacional de Energia Elétrica. $B I G$ Banco de Informações de Geração. 2015. Available at: $<$ http://www.aneel.gov.br/area.cfm?idArea=15>. Access: 01.09.2015.

Bebbington, A.; Bebbington, D. H.; Bury, J.; Lingan, J.; Muñoz, J. P.; Scurrah, M. Mining and Social Movements: Struggles Over Livelihood and Rural Territorial Development in the Andes. World Development, 36(12), 2888-2905, 2008. doi: 10.1016/j.worlddev.2007.11.016

Bermann, C. Os limites dos aproveitamentos energéticos para fins elétricos: uma análise política da questão energética e de suas repercussões socioambientais no Brasil. Campinas, Tese (Doutoramento) - FEM/UNICAMP, 1991.

Buchanan, K. S. Contested discourses, knowledge, and socio-environmental conflict in Ecuador. Environmental Science and Policy, 30, 19-25, 2013. doi:10.1016/j.envsci.2012.12.012

CNEC Worley Parsons. Aproveitamento Hidrelétrico (AHE) São Luiz do Tapajós: Estudo de Impacto Ambiental (EIA). Vol. 1 - 25, 2014. Available at: <http://licenciamento.ibama.gov.br/Hidreletricas/S\%C3\%A3o\%20Luiz\%20do\%20 Tapajos/EIA_RIMA/>. Access: 20.01.2016.

Diálogo Tapajós. Perguntas e respostas sobre os estudos de viabilidade da Usina São Luiz do Tapajós. Itaituba, n.d.

Eletrobras. Sistema de Informações do Potencial Hidrelétrico Brasileiro (SIPOT), 2014. Available at: $<$ http://www. eletrobras.com/elb/data/Pages/LUMIS21D128D3PTBRIE. htm>. Access: 23.10.2015.

El Saifi, S.; Dagnino, R. S. Grandes projetos de desenvolvimento e implicações sobre as populações locais: o caso da usina de Belo Monte e a população de Altamira, Pará. Ipea, Anais do I Circuito de Debates Acadêmicos, 2011.
EPE - Empresa de Pesquisa Energétrica. Balanço Energético Nacional 2015: Ano base 2014. Rio de Janeiro, 2015

Fearnside, P. M. Hidrelétricas na Amazônia: impactos ambientais e sociais na tomada de decisões sobre grandes obras. V. 1. Manaus: Editora do INPA, 2015a

Fearnside, P. M. Brazil's São Luiz do Tapajós Dam: The Art of Cosmetic Environmental Impact Assessments. Water Alternatives, 8(3): 373-396, $2015 \mathrm{~b}$.

Feenberg, A. Subversive rationalization: technology, power and democracy. Inquiry, 35(3/4), 301-322, 1992.

Gaviria, G. A. M. Formas de violencia en la construcción de la Central Hidroeléctrica Porce III en Antioquia - Colombia. WATERLAT - GOBACIT Network Working Papers Thematic Area Series, TA2 Water and Megaprojects, 2(2), 59-81, 2015. Available at: <http://waterlat.org/WPapers/ WPSATAM22.pdf $>$. Access: 28.04.2016

Giesecke, J.; Heimerl, S.; Mosonyi, E. Wasserkraftanlagen: Planung, Bau und Betrieb. 6.Auflage. Berlin: Heidelberg: Springer Vieweg, 2014.

Gobbi, F. P. Brazil's Belo Monte Dam project: Financial impact, indigenous peoples' rights \& the environment. Library of the European Union, 2013.

Gómez Fuentes, A. C. La construcción de conocimiento antropológico como una forma de violencia epistemológica en los conflictos por megaproyectos hídricos en México. WATERLAT - GOBACIT Network Working Papers Thematic Area Series, TA2 Water and Megaprojects, 2(2), 82-101, 2015. Available at: <http://waterlat.org/WPapers/WPSATAM22.pdf $>$. Access: 28.04.2016.

Hernández, D. Sacrifice Along the Energy Continuum: A Call for Energy Justice. Environmental Justice, 8(4), 2015. doi: 10.1089/env.2015.0015

IEA - International Energy Agency. Key World Energy Statistics 2014. Paris: IEA Publications, 2014.

Instituto Acende Brasil. Povos indígenas e o setor elétrico: do conflito ao consenso. White Paper 12, São Paulo, 2013.

Kumar, D.; Katoch, S. S. Sustainability indicators for run of the river (RoR) hydropower projects in hydro rich regions 
of India. Renewable and Sustainable Energy Reviews, 35, 101-108, 2014. doi: 10.1016/j.rser.2014.03.048

Martínez Alier, J. O ecologismo dos pobres: conflitos ambientais e linguagens de valoração. 2. ed. São Paulo: Contexto, 2007.

McCully, P. Silenced Rivers: The ecology and politics of large dams. London: Zed Books, 2001.

Mendonça, R.; Barros, N.; Vidal, L. O.; Pacheco, F.; Kosten, S.; Roland, F. Greenhouse Gas Emissions from Hydroelectric Reservoirs: What Knowledge Do We Have and What is Lacking? In: Liu, G. (Ed.). Greenhouse Gases: Emission, Measurement and Management. InTech, 2012. doi: $10.5772 / 32752$

MME - Ministério de Minas e Energia. Plano Decenal de Expansão de Energia 2023. Brasília, 2014.

Moreno Jiménez, A. Justicia Ambiental: Del concepto a la aplicación en planificación y análisis de políticas territoriales. Scripta Nova, XIV(316), Universidad de Barcelona, 2010. Available at: $<\mathrm{http} / / / w w w . u b . e s / g e o c r i t / s n / s n-316$. html>. Access: 13.01.2016

Morimoto, R. Incorporating socio-environmental considerations into project assessment models using multi-criteria analysis: A case study of Sri Lankan hydropower projects. Energy Policy, 59, 643-653, 2013. doi: http://dx.doi. org/10.1016/j.enpol.2013.04.020

Nascimento, E. P. Os conflitos na sociedade moderna: uma introdução conceitual. In: Bursztyn, M. (Ed.). A difícil sustentabilidade: política energética e conflitos ambientais. Rio de Janeiro: Garamond, 2001.p. 85-105.

Pinto, L. F. Grandezas e misérias da energia e da mineração no Pará. In: Sevá Filho, A. O. (Ed.). Tenotã-Mõ: alertas sobre as consequências dos projetos hidrelétricos no rio Xingu. São Paulo: International Rivers Network, 2005. p. $95-113$.

Poma, A. Que précios tienen nuestras raíces? Una propuesta analítica para comprender los conflictos ambientales. In: Ribeiro, W. C. (Ed.). Conflitos e cooperação pela água na América Latina. São Paulo: Annablume, 2013. p. 265-292.

Poma, A.; Gravante, T. Analyzing Resistance from below: A Proposal of Analysis Based on Three Struggles against Dams in Spain and Mexico. Capitalism Nature Socialism, 2015. doi: 10.1080/10455752.2014.995688
Ribeiro, W. C. Socio-Environmental Theories: Seeking a New Society. Estudos Avançados, 24(68), 9-13, 2010. doi: 10.1590/S0103-40142010000100003

Ribeiro, W. C. Gás “de xisto" no Brasil: uma necessidade? Estudos Avançados, 28(82), 89-94, 2014. doi: 10.1590/ S0103-40142014000300006

Romero, H.; Méndez, M.; Smith, P. Mining Development and Environmental Injustice in the Atacama Desert of Northern Chile. Environmental Justice, 5(2), 2012. doi: 10.1089/env.2011.0017

Rosa, L. P. Hidrelétricas na Amazônia: entre o pragmatismo e a utopia. In: Val, A. L.; Santos, G. M. (Eds.). Grupo de Estudos Estratégicos Amazônicos (GEEA), Tomo VI. Manaus: Instituto Nacional de Pesquisas da Amazônia (INPA), 2013, p. 13-25.

Sachs, I. Barricades of Yesterday, Building Sites of the Future. Estudos Avançados, 24(68), 25-38, 2010. doi: 10.1590/ S0103-40142010000100005

Schlosberg, D. Defining Environmental Justice: Theories, Movements, and Nature. New York: Oxford University Press, 2007.

Sclove, R. E. Design Criteria and Political Strategies for Democratizing Technology. In: Schomberg, R. (Ed.). Democratising technology: theory and practice of deliberative technology policy. Hengelo: International Centre for Human and Public Affairs, Buenos Aires, p. 17-38, 1999.

Sevá Filho, A. O. Estranhas catedrais. Notas sobre o capital hidrelétrico, a natureza e a sociedade. Ciência e Cultura, São Paulo, 60(2), 2008.

Siciliano, G.; Urban, F.; Kim, S.; Lonn, P. D. Hydropower, social priorities and the rural-urban development divide: The case of large dams in Cambodia. Energy Policy, 86, 273-285, 2015. doi: 10.1016/j.enpol.2015.07.009

Skinner, J.; Haas, L. J. Watered down? A review of social and environmental safeguards for large dam projects. Natural Resource Issues, London: IIED, 28, 2014.

Sparkes, S. Hydropower development and food security in Laos. Aquatic Procedia 1, 138-149, 2013. doi: 10.1016/j. aqpro.2013.07.012

Sousa Junior, W. C.; Bermann, C. Hydropower - The Sustainability Dilemma. In: Samadi-Boroujeni, H. (Ed.). 
Hydropower: Practice and Application. InTech, 2012. doi: $10.5772 / 34242$.

Souza, A. N.; Jacobi, P. R. Hidrelétricas na Amazônia: entre uma nova esfera pública e a modernização ecológica. In: Ribeiro, W. C. (Ed.). Conflitos e cooperação pela água na América Latina. São Paulo: Annablume, 2013. p. 321-342.

Tilt, B.; Braun, Y.; He, D. Social impacts of large dam projects: A comparison of international case studies and implications for best practice. Journal of Environmental Management, XXX(1-9), 2008. doi:10.1016/j.jenvman.2008.07.030

Vainer, C. B. Recursos hidráulicos: questões sociais e ambientais. Estudos Avançados, 21(59), 119-137, 2007. doi: 10.1590/S0103-40142007000100010

Ventura Filho, A. Aproveitamento do Potencial Hidrelétrico Nacional: alternativas após o seu "Esgotamento". The Electricity Sector \& New Global Frontiers Conference,
Instituto Acende Brasil, São Paulo, 2015. Available at: $<$ http://www.brazilenergyfrontiers.com/media/filemanager/ AltinoVentura\%20\%281\%29.pdf $>$. Access: 30.04.2016.

Von Sperling, E. Hydropower in Brazil: overview of positive and negative environmental aspects. Energy Procedia, 18(110-118), 2012. doi: 10.1016/j.egypro.2012.05.023

WCD - World Commission of Dams. Dams and Development: A new framework for decision-making. London: Earthscan Publications, 2000.

WCED - World Commission on Environment and Development. Report of the World Commission on Environment and Development: Our Common Future. 1987. Available at: <http://www.un-documents.net/our-common-future. pdf>. Access: 20.01.2016.

Zhouri, A. (Ed.). As tensões do lugar: hidrelétricas, sujeitos e licenciamento ambiental. Belo Horizonte: Editora da UFMG, 2011. 